\title{
Responses to Racism within Black Families in Cartagena de Indias*
}

\author{
KRISTELL VILLARREAL BENÍTEZ ** \\ HEIVER MARRUGO MONTERROSA** \\ JAVIER RÍOS FERNÁNDEZ *** \\ ANA CECILIA OCHOA RAMOS ${ }^{* * * *}$
}

Recepción: 5 de septiembre de 2019

Aprobación: 20 de diciembre de 2019

Forma de citar este artículo: Villarreal, K. Marrugo, H. Ríos, J. \& Ochoa, A.C. (2020). Responses to Racism within Black Families in Cartagena de Indias. Cuadernos de Lingüística Hispánica, (35), 57-80.

(9) https://doi.org/ 10.19053/0121053X.n35.2020.10509

* Artículo de investigación.

** Magíster en Antropología Social de la Universidad Nacional de Colombia, miembro del grupo de investigación TEXCULTURA de la Universidad de Cartagena. Correo electrónico: Kristell-villarreal@outlook.es (D) https://orcid.org/0000-0002-3787-3601

*** Magíster en Derecho de la Universidad de Cartagena. Profesor del Tecnológico de Comfenalco. Correo electrónico: hmonterrosaabogado@gmail.com (iD https://orcid.org/0000-0003-1641-4657

**** Candidato a magíster en Educación, miembro del grupo de investigación TEXCULTURA de la Universidad de Cartagena. Correo electrónico: Javi-1089@hotmail.com (iD) https://orcid.org/0000-0003-1247-1400

****** Magíster en Educación de la Universidad Tecnológica de Bolívar. Correo electrónico: anyceci102010@gmail.com (DD https:// orcid.org/0000-0003-0901-1593 


\section{Abstract}

This article describes some of the responses to everyday racism that occurs within some black families from Cartagena. The categories of analysis of this work were established from the forms of everyday racism conceptualized by Philomena Essed (1991). The data used were obtained through twenty semi-structured interviews. We worked with people who recognize themselves as black, the practices they described took place within the family nucleus where they were formed, but also the family nucleus that they formed during their adulthood.

It is concluded that in many black families from Cartagena are spaces where identity is managed and where the pillars are built, so that subjects can acquire tools that allow them to improve their capacity for social mobility, but it is also a space where racist ideologies can be (re)produced under a protectionist and paternalistic premise.

Keywords: Cartagena; family; everyday racism;race.

\section{Respuestas al racismo dentro de la familias negras en Cartagena de Indias}

\section{Resumen}

Este artículo describe algunas de las respuestas al racismo cotidiano que se presenta en las familias negras cartageneras. A partir de las formas de racismo cotidiano conceptualizadas por Philomena Essed (1991), se establecieron las categorías de análisis de este trabajo. Los datos usados fueron obtenidos a través de veinte entrevistas semiestructuradas. Los participantes fueron personas que se reconocen como negras, quienes usaron sus propias experiencias dentro del núcleo familiar donde se formaron, pero también de los núcleos que conformaron posteriormente.

Se concluye que la familia negra cartagenera es un espacio donde se gestiona la identidad y se construyen los pilares para que los sujetos puedan hacerse a herramientas que les permitan mejorar su capacidad de movilidad social, pero también es un espacio donde las ideologías racistas pueden ser (re)producidas bajo premisas proteccionistas y paternalistas.

Palabras claves: Cartagena; familia; racismo cotidiano;raza. 


\section{Réponses au racisme au sein des familles noires à Carthagène des Indes}

\section{Résumé}

Cet article décrit quelques-unes des réponses au racisme quotidien dont sont victimes les familles noires de Carthagène. Ayant comme point de départ des formes de racisme quotidien conceptualisées par Philomena Essed (1991), nous avons établi les catégories d'analyse de ce travail. Les données utilisées ont été obtenues à l'aide de vingt entretiens semi-structurés. Les participants, se reconnaissaient noires, ont tenu en compte de leurs expériences à l'intérieur de la famille où ils ont grandi, et ils ont fait appel aux souvenirs des familles qu'ils ont formées plus tard. Nous pouvons en conclure que la famille noire de Carthagène est un espace où l'on construit une identité et c'est là que l'on fournit les bases qui permettent aux sujets d'améliorer leurs possibilités de mobilité sociale. Elle est aussi un espace où les idéologies racistes peuvent être (re)produites sous des prémices protectionnistes et paternalistes.

Mots clés: Carthagène; famille; racisme quotidien; race.

\section{Respostas ao racismo dentro de famílias negras em Cartagena de Indias}

\section{Resumo}

Este artigo descreve algumas das respostas ao racismo cotidiano que ocorrem nas famílias negras de Cartagena. Com base nas formas de racismo cotidiano, conceituadas por Philomena Essed (1991), foram estabelecidas as categorias de análise deste trabalho. Os dados utilizados foram obtidos através de vinte entrevistas semiestruturadas. Os participantes foram pessoas que se reconheceram como negras, que usaram suas próprias experiências dentro do núcleo familiar em que foram formados, mas também dos núcleos que mais tarde formaram. Conclui-se que a família negra de Cartagena é um espaço onde a identidade é gerenciada e os pilares são construídos para que os sujeitos possam usar ferramentas que lhes permitam melhorar sua capacidade de mobilidade social, mas também é um espaço onde as ideologias racistas podem ser reproduzidas sob premissas protecionistas e paternalistas.

Palavras-chave: Cartagena; família; racismo diário; raça. 


\section{Introduction}

Understanding speech as a form of social practice implies recognizing the existence of a kind of dialectical relationship between situations, social structures, institutions, subjects and the discursive event that is taking place. It is not possible to produce a discourse without context, so it is not possible to understand it without taking into account the context (Fairclough \& Wodak, 2000, p. 394). Cartagena de Indias is a city with a colonial past that strongly affects both social structures and socio-racial hierarchies and the interaction that occurs within the framework of these conceptualizations. It is considered a society with many socioeconomic differences among its population. Those differences maintain a proportional relationship with the ethnic-racial category to which individuals "belong".

Like discourse, understanding racism implies the understanding that racist ideologies are not universal. All those ideologies are particular and consequences of specific and situated historical processes, to that extent, "racial" differences vary and conform to the contexts where they are built. Colombian racism is strongly associated with phenotypic traits, "blackness" manifests itself through the way subjects look, since attitudes, moral attributes and even intellectuals are granted to these bodies (Zebrowitz, 1996; Cunin, 2003; Gil, 2010).

If we talk about racism that occurs in the city, it has been described by many, including us, as a persistent, overlapping and naturalized racism. In Cartagena there are no blacks, there are piel canela ${ }^{1}$, canelita Hollywood ${ }^{2}$ or café con leche $e^{3}$ people. Cartagena is a city that deals with "black" through the gray areas. We can even talk about a type of racism that gives green light to the negotiation and only can be understood when the city is known in depth ${ }^{4}$.

The family is a social institution. It is a space where there are tensions associated with power relationships and ideologies, as well as a space where there is a tendency to protect its members. As a place, families have the potential for anti-racist struggles (Nelson \& Dunn, 2017), yet, racist ideologies are continuously (re)produced within them, the latter legitimized under the premise that members will be safeguarded if they adopt and assume certain attitudes or do not alter the statu quo established in the society.

1 Skin like cinnamon, tan skin color.

2 A tan skin color that someone living in Hollywood has.

3 Café Au Lait.

4 If you want to deepen this section, please review the article "Managing Identity: Hair as Capital" (2018) published in Revista Brasileira do Caribe. 
Through this work we seek to highlight the central role played by the family in the processes of racial socialization in the development of a racial attitude and the conformation of a racial identity, all of the above associated with a series of categorizations inserted within the notion of "everyday racism" coined by Philomena Essed (1991). It is necessary to emphasize that we know very little about the way members of a family nucleus negotiate the instances of racism, the strategies that are implemented to subvert it and the structural configurations of systemic and internalized racism that appear in a private context as the family.

Racism as a subject is thorny, always bringing complications in terms of approach. Now, adding the family dimension to racism makes the situation more complex. This is due to the fact that the experiential overcomes the physical and interferes in the field of emotion and affection. Whereas that the task of socialization is shared among the extended family, the people from school, the neighborhood, and in many cases the church, the primary responsibility lies in parents (White-Johnson, Ford \& Sellers, 2010); those messages end up being apprehended by socialized individuals, and become the guidelines that socialized subjects will use to live in society. From a phenomenological perspective, we learn through experience and, in fact, the experience is conceived as a main source of knowledge (Beharry \& Crozier, 2008; Staudigl, 2012). However, in families, the speech factor also plays a relevant role.

The referential experiences used by people who prepare children to acquire their roles in society are a permanent source of racial knowledge. It is through the narratives that many agents of socialization show children how difficult it is to live in Cartagena, and through the discourse, they seek to avoid their children experience what they went through at some point in their lives.

Families, in general, are constituted as spaces full of complexities, and by being social institutions, they help to transmit to the most recent members of the family those ideological elements that circulate and are produced in society. The transmission of knowledge is not something that happens randomly or by socializing automatisms; ${ }^{5}$ on the contrary, intervention in the socialization process is the result of reflections and full

5 Based on the phenomenological assumption that allows creating a causal relationship between lived experience and the formation of knowledge, this term emerges as a way of referring to that knowledge constructed by an individual based on her/ his own experience and subsequently is generationally transmitted as an undeniable and a prevailing truth. The concept is interesting because there is no real experiential root in who is transferring knowledge, but rather, legitimization is given using the logical fallacy ad antiquitatem. Additionally, such knowledge may affect very specific aspects of the subject's life, such as the places she/he visits, the color of the clothes she/he wears or the predisposition towards certain situations. 
awareness of specific but silenced events, all those insights play a decisive role in the selection of the knowledge that will be transmitted.

\section{Theoretical and Methodological Framework}

This article reveals the forms of daily racial discrimination that occur within a group of black families in Cartagena, Colombia. The data presented are part of the database of the TEXCULTURA research group. We worked with a group of twenty interviews made to people who recognized themselves as Afro-descendants. The results presented here are part of a macro-project where the forms of racism that were experienced in different areas of the city were addressed, and finding numerous mentions of families in the interviews we decided to include the family/home as a space. The above explains why a characterization of families per se could not be established, since we worked with the narratives about them made by the participants. We can understand racism as a system of meaning that provides a referential framework from which the world is understood, as an ideology used to mark distances among individuals and exploit those that are conceptualized as minorities (Bonilla, 1997). Essed (1991) explains that racism is a structure inserted in the social system and a process integrated into common, current and routine practices. But it is also a social practice that manifests in institutions, discourses, and interactions (Quintero, 2010).

Essed, when referring to everyday racism, establishes a particular way of understanding the complexities of those people who have been its victims, who have felt the rigor of racism. An approach based on this notion demands a reflection on personal encounters and lived experience. In this specific type of racism, the structural and ideological dimensions are found in situations lived during the everydayness, and it is through family practices that the problematization of the Other is naturalized and racism is normalized. It is necessary to emphasize that when we use the term "race" we do not intend to affirm that it exists as a biological reality, on the contrary, for this research it was understood as a social construction (Bonilla, 1997; Viveros, 2009; Quijano, 1999; Villarreal, 2018; Wade, 1997, 2003), as an ideological construct created during the Colony (Quijano, 2000).

The discursive analysis in this research was made using the Critical Discourse Analysis (CDA). The excerpts of interviews cited in this work are part of the data bank of the TEXCULTURA ${ }^{6}$ research group. This data bank is constituted by twenty interviews

6 Text, discourse, and culture in the Colombian Caribbean. 
conducted between 2006 and 2009 to people from Cartagena who recognize themselves as black. The stories were characterized by having a sequence in terms of stages of life. For that reason, it was possible to deepen considerably in childhood. Just as the informants stated several relevant aspects of the education they had in their homes, they also mentioned how they are raising their children.

The organization of the experience was carried out through the model provided by Philomena Essed (1991), that is, using the categories of marginalization, problematization and containment, in addition to the subcategories registered to each one. However, the characterization was made using the responses to the racism that, according to the participants, were produced in their families. In general, they focused on the problematization as the axis from which the development of the tools of social survival emerges. We understand the problematization as the attribution of negative attitudes and characteristics by a group towards those perceived as the 0thers. This attribution functions as a way to legitimize exclusion -marginalize- and to restrict any form of opposition or resistance -contain- (Essed, 1991; Fonseca, 2014).

\section{Results}

Racial socialization as a parenting strategy consists of conversations about racial issues with children in the family, in order to prepare them to face, in some point in their lives, racial discrimination (Hughes et al., 2006; Hughes \& Chen, 1999; Davis, SmithBynum, Salem, Francois \& Lambert, 2017). The socializing messages with racial content mentioned by our participants have been built on many of the negative beliefs shared by members of the Cartagena society. An incautious look would mark the previous as obvious, due to the tacit impact that essentialist ideas have on black people. However, the fact that within the black families they (re)produce repeatedly such beliefs exposes, apparently, a relationship of complicity between victims and victimizers:

(1.) "Since I was little, she used to tell me this, mija, you're too black to wear those colors; they look good on white people, you do not look good in those colors". (Ana, 2006).

"Desde pequeña me decía ella así, mija, tú eres muy negra pa’ponerte esos colores, esos le quedan bien es a las blancas, a ti no te quedan bien esos colores".

(2.) "My mom, she said when we were younger, -that I was that way smug, smug you know people who do not like to eat at all, I was born in a house of rich people 
in Venezuela, so I ate what... If it was the chicken, the leg or the breast, if it was fish, it had to be (fried) then I was the lack of the house ... YOU want to eat as a white person". (Adolfo, 2009). "Mi mamá, decía cuando estábamos más pequeños, -que yo era así facto, facto - tú sabes gente que no le gusta comer de todo, yo como nací en una casa de gente rica en Venezuela, entonces yo comía, lo que... Si era el pollo, muslo, la pechuga, si era pescado, tenía que ser (frito) entonces yo era el falco de la casa... TÚ quieres comer como blanco”.

This premise should be understood as related to survival. We speak of people who recognize racism as a persistent social problem that has a high cost for those who experience it as victims, costs ranging from seemingly simple events, such as establishing a sentimental relationship, to more complex situations, such as the denial of access to health services or education (William \& Collins, 2001; Fonseca, 2014).

While the messages achieve a strengthening of stereotypes and a reproduction of racism, from the place of enunciation of these people, they are a way that has helped them to live a life without problems, and that will help future generations to live without having to face the rigors of racism.

Socialization messages that are issued within black households, function as discursive responses and as effective actions for the preparation of children. From the information found we defined a typology that was divided into four categories: biological, cultural, behavioral and verbal (see Table 1). This typology only provided an overview of the responses produced by families in order to promote the adjustment process of children, so that they can adapt to the social environment.

Table 1. General and specific responses to racism

\begin{tabular}{|l|}
\hline General responses to racism \\
\hline Biological \\
Cultural \\
Behavioral \\
Verbal \\
\hline
\end{tabular}


Tabla 1. Cont.

\begin{tabular}{|c|}
\hline Specific responses to racism \\
\hline $\begin{array}{l}\text { Whitening } \\
\text { Racist discourse } \\
\text { Avoid entrance to white people institutions } \\
\text { Welcome them with mercy } \\
\text { Preference of some individuals to others } \\
\text { Reject submission } \\
\text { Demand additional efforts } \\
\text { Moving out of the black neighborhood } \\
\text { Self-underestimation } \\
\text { Self-compassion } \\
\text { Self-representation } \\
\text { Send projective messages } \\
\text { Reject them } \\
\text { Reject ethnic behavior } \\
\text { Acknowledge stereotypes } \\
\text { Acknowledge racism }\end{array}$ \\
\hline
\end{tabular}

\section{Whitening and Self-Representation "pa'componé la raza": The Biological Dimension of the Responses to Racism}

References to the somatic traits of black people ${ }^{7}$, such as their lips, their skin color, the type of hair or their nose appeared very frequently within the statements made by the agents of socialization. The phenotypic characterization that they did was used as parameters to define in a precise way which attributes of the body should be modified, since these are not positively perceived in the society of Cartagena. Therefore, ways of transforming these traits are measured in order to counteract racism. The results indicate that the answers are framed within the category that Essed called "recognize stereotypes" and respond to two specific subcategories "whitening" and "self-representation", all coinciding in the physical factor as a problematic axis.

Whitening, as a mechanism of social improvement, associated with the search for a whiter spouse to ensure offspring with lighter skin and hair with less curls leads to the concealment of black physical elements and reinforces the designation of "blackness" as something related to poverty, ugliness and criminality (Posada, 2003, p. 108).

$7 \quad$ Categories such as "white" and "black" are under discussion. Nevertheless, they are used in this paper taking into consideration those meanings given by people from Cartagena. 
(3) My grandmother, when my brothers began to have girlfriends // she used to constantly tell them / we would tell her enough / that we find, that we find people / with fair skin, and that in order to mend the race, she supposed / or still supposes / that black people need to marry white people, so that they won't be mistreated/." (Adolfo, 2006)

"Mi abuela, cuando ya mis hermanos comenzaron a tener novias// ella les, les decía bastante / que buscáramos, que encontráramos personas/más claritas, $y$ que pa'componer la raza ella suponía/ o supone todavía/ que los negros tienen que casarse con un blanco, para que no los maltraten/."

Whitening in Cartagena is a reality accepted, possible and sought, that is related to the admitted conceptualizations of race in the city. This notion has, according to the analysis of the participants' discourses, a biological counterpart that is inherited but can be altered having a direct resonance within the social ascent. So, we could think of a series of elements that function as buffers for the continuum of racial categories in the city, that is, things that help a person becomes less black and can allow her/him to access spaces, resources, and relationships that are presumed to be prohibited to black people in the city.

The agents of socialization demand that those who are new members in the family exhibit "white" traits, in such a way that they can be perceived as such. The prior idea reveals how the whitening ideologies that Peter Wade (2003) talks about "favor whites and belittle the blacks and the indigenous people" (p. 286). Nevertheless, the experiences collected reveals that for black people, racism is lived with and $i n$ the body. The physical degradation suffered historically by black people for centuries has culminated in an introjection of the Eurocentric aesthetic canons that preside over the western and capitalist culture that governs us. The rejection of the "black" body no longer originates only among those who possess resources and hold power, but also among members of the affected group that has internalized and has made these discriminatory ideas their own (Hargro, 2011; Ellis-Hervey, Doss, Davis, Nicks \& Araiza, 2016)

(4) Within the family directly you can't see it but yes, there is a rejection to that we will suddenly have more contact with (with) black people, that is, I imagine that my dad thought about my daughter's boyfriend shouldn't be black. Yes! Shouldn't be black, although he still does not ... he has not told me, he always has, he always has that into account. That at least within the family/ the fact that conversations or internal dialogs are generated all the time, is marking that that rejection to join more black members to the family. That is, do not join more black people, it is like "we are complete and from here we must improve the physical traits and hair", because we don't even talk about the feeling or any 
other element but those characteristics (...) ehmm, it is necessary to improve in that, the nose is necessary to put it more pointy, the hair, we must try to putting it more straight, yes!, no longer so kinky (...) And those characteristics are worked through the genes, then from that (...) point of view we talk about improving. It is like race needs to be improved. Yes!, ehmm He has not told me directly but that is it". (Miladys, 2009)

"Dentro de la familia, lo que así directamente no se ve, pero sí hay (un) rechazo a que tengamos de pronto más contacto con (con) personas negras, o sea yo me imagino que mi papá estará pensando en que los novi el novio de mi hija no debe ser negro. iSí!, no debe ser negro, aunque él todavía no me... él no me lo haya dicho, él siempre tiene... siempre se tiene en cuenta eso. Que por lo menos dentro de la familia el becho de que todo el tiempo se generen conversaciones internas o diálogos, está marcando ese esa ese como ese rechazo a vincular más miembros negros a la familia. O sea, no vinculemos más negros, así como que los que estamos estamos completo' y de aquí pa 'lante ya bay que mejorar las facciones físicas $y$ y el cabello, porque no se babla ni siquiera ese sentimiento ni de otro elemento sino sino esas características (...) eb hay que mejorar en que la nariz hay que ponerla más fina, en que el cabello bay que tratar de de de ponerlo más liso, isí!, ya no tan ensortijado (...) Y esas características se trabajan con los genes, entonces desde ese (...) punto de vista se habla de la de mejorar. Como hay que mejorar la raza. iSí!, eeh no me lo ba dicho directamente, pero eso es".

People recognize that traits that diversify subjects are the elements that hegemonic groups use to be able to classify them as Others and make them objects of denigration, paternalism or invisibility (Bellinger, 2007; Bankhead \& Johnson, 2014). They recognize that somatic traits are not only used as an excuse to segregate and exclude, but also to exercise aesthetic judgments.

(5) But Andres is very ugly, look at those eyes". And I say to him: "now you are going to say that ... he has a big mouth, that he is a thick-lipped, that all blacks are thick-lipped for you, that they have big eyes, that he has a nose" (Merly-15).

"Pero es que Andrés es muy feo, mírale esos ojos". Y yo le digo: "ahora vas a decir que... tiene la boca grande, que es bembón, que todos los negros son bembones para ti, que tienen los ojos grandes, que tiene la nariz”.

Some of our participants said that in their homes they were taught "not to recognize themselves as blacks" which may be another sign of complicity. However, we consider that 
part of the intention of those who are socializing is to provide their knowledge about black people, to help them identify themselves as different in any way, probably as a mean to keep them away from fight against race discrimination by assuming that "it is not something that concerns them", all within what we understand as the protection framework:

(6) "My sister (...) says she is not Black, and in the..., I do remember, in the family she said I am not Black, and then that she was, denying her color, of course" (Martha, 2009).

"Mi hermana (...) dice que no es negra y en la ... eso sí recuerdo, en la familia decía yo no soy negra, y entonces que era, negándose el color, eso sí".

(7) "When I was a kid, I did not think it was black, I used to hear about Afro issues, about negritude, I thought that did not have to do with me." (Pedro, 2006).

"Cuando estaba pelao yo no creía que era negro, yo escuchaba bablar de la problemática afro, de las negritudes, yo creía que eso no era conmigo”.

These responses are within the framework of the recognition of stereotypes about bodies, that spread a set of ideas that are not originally shared within their social group but are assumed, internalized and learned as part of the dynamics of power and hierarchies founded on the idea of race in Cartagena.

\section{"Ya todas las cosas que él va a tener en su casa son de gente blanca": The Cultural Dimension of the Responses to Racism}

The answers in this category were subdivided into two different types (i) those that positively allude to the cultural elements of black people and (ii) those that negatively refer to practices, beliefs, and values associated with black people. Which is directly related to the notion of private regard refers to the extent to which African Americans' personal assessment of their positive or negative feelings about being African American and towards African Americans in general (Davis et al., 2017).

The experiences narrated by our participants expose the conclusion reached by many victims of racism: they assume that the best way to contend racism and survive it is to resort to an improvement in aesthetics, a higher academic performance or an increase in the economic capital. In fact, many of our participants indicated that their parents demanded and forced them to use specific colors at the time of dressing, they instilled in them the need to study and they learned that the ideal is always to look for a better socioeconomic condition: 
(8) "I used to tell her, "mommy, but I like it, I like those colors and do not buy other colors for me because I do not want to, I want those colors", but she, as she was always the one who paid for clothes, imposed her will and always dressed me in colors or pastel shades "(Ana, 2006)

"Yo le decía, "mami, pero es que a mi me gustan, a mí me gustan esos colores y no me compre otros colores porque yo no quiero, yo quiero esos colores"; pero ella, como era quien siempre compraba la ropa, se imponía y siempre me vestía era de colores o de tonos pasteles".

(9) "What they told you was that you had to study, to train yourself, because here [Cartagena] they did not want them [Black people] and sometimes they are trained and they do not want them, so you have to make them respect you, that is, they put the complex in your head. you are at a disadvantage, because it is true" (Pedro,2006).

"Lo que te decían era que tenías que estudiar, que capacitarte, porque aquí a los Negros no los querían y a veces están capacitados y ni así los quieren, entonces tienes que bacerte respetar, o sea, te van metiendo el complejo en la cabeza de que estás en desventaja, porque es verdá”.

(10) "Yes, this is especially true in families that are having a certain ... Someone stratum 2 begins to acquire some economic comfort leaves Nelson Mandela (...) that someone is acquiring another attitude and suddenly has the possibility, and then move to Las Gaviotas ${ }^{8}$ changing, it's something else, she/he is already feeling, she/he stops being Black and she/he does not give up, she/he is already starting to question (her)himself, she/he is starting to question (her)his, (her)his, (her)his, (her)his life as Black and (her)his situation as Black and all the things that she/ he is going to have in (her)his house are of White people, and the aspirations that she/he is going to have, are the same that the Whites aspire to." (Pedro, 2006).

"Sí, así se hace sobre todo en las familias que van teniendo cierto... uno de estrato 2 empieza a adquirir cierta comodidad económica va saliendo de Nelson Mandela (...) va adquiriendo otra actitud y de pronto tiene la posibilidad y entonces se mudan pa' las Gaviotas cambiando, ya es otra cosa, ya va sintiendo, deja de ser Negro ya no se resigna, ya empieza a cuestionarse, ya empieza a cuestionarse su, su, su, vida de Negro y su situación de Negro y ya todas las cosas que él va a tener en su casa son de gente Blanca, ya las aspiraciones que va a tener, son las mismas que aspiran los Blancos". 
The response within many families to the cultural denigration originates from the hegemonic group. According to the experiences of our participants, it is to begin to undervalue their own practices and costumes, this implies recognizing and accepting the underestimation incorporated into the discourses. Many members inside families assume being black as a condition. They accept that as afro-descendants, they do not have a high level of learning and that is why some cannot access certain jobs or study certain careers. They conclude that the poverty of black people is related to their inability to appropriate certain knowledge and develop it in its multiple dimensions.

(11) "Sometimes we are studying and we have all the professions and nobody... It's the "but" situation, you always hear "he's black, but" ...: "that is a negro, but he's elegant, or he's smart, or he is... that, that "but" is hurting you". (Pedro, 2006)

"Fíjate que a veces estamos estudiando y tenemos todas las profesiones y nadie... iah! Y la cuestión esa del 'pero', siempre oyes él es negro, pero es elegante o pero es inteligente 0 es... eso, pero ese 'pero' te va haciendo daño".

(12) "My dad is a very shy person; he talks very little, because of that same condition [being a black person]. (...) Because of that same condition. Then he ..., sometimes... he always says -we are Black and disgusting-I tell him 'daddy, but do not say that, we all have the same rights"'. (Ana, 2006)

"Mi papá es una persona bastante tímida; él es de poco hablar, por esa misma condición. [ser una persona negra] (...) Por esa misma condición. Entonces él..., él a veces... siempre dice -nosotros como somos Negros y malucos- yo le digo papi, pero no digas eso, que todos tenemos los mismos derechos".

(13) She says "oh yes Carmen, I had to buy that storybook to my child, because we're watching a movie, and he says: "mommy" -the kid only is five years old-, "mom, who is he?", then she told him: "he is the doctor".

"The doctor!? No mommy, Black people aren’t doctors". (Carmen, 2006)

"Me dice: ay sí "Carmen", tú no sabes que tuve que comprarle ese cuento al niño. Porque estábamos viendo una película, y me dice, 'mami -el niño tiene cinco años-, ¿mami y él quién es?' Entonces ella le dijo: ese es el doctor.

¿El doctor? No, si los Negros no son doctores". 


\section{"Yo llegué a pensar: ierda! eipero por qué soy así negro!? esi me entiendes?: The Behavioral Dimension of the Responses to Racism}

In this category, it is possible to find those responses that are posted as attitudinal reactions to the racist situations that have been experienced at some time. The personal characteristics of the agents of socialization are being black, and belong to a conflictive society, as it is Cartagena. We found that self-pity was a constant response to the racial circumstances of the city; parents through the acceptance of cultural and phenotypic stereotypes allow children to foster negatives ideas that influence their own construction of identity. Parental messages that emphasize the realities of the discrimination allow development of self-perception as a victim, which can produce negative feelings about being African-descendant (Davis et al., 2017; McRoy, 1996). We find some sorts of contradictions among imagen of people who are looking at themselves in the mirror and the image that parents are trying to build. To that extent, many spoke to us about the racial questions they had at some point in their lives.

(14) "Things like these immediately and to me, since I was little, from a very young age, I began to notice that something was not right. Yes. And, I realized that, that was not only in my family, but there was a level of nonconformity. I came to think: 'but why? Why am I black?' Do you understand me? Everything...”. (Carlos, 2006)

"Cosas como estas de inmediato ya a mi me, de de desde muy pequeño, desde muy corta edad, comencé a notar que algo no estaba bien. Sí. Y me di cuenta que, eso no era solamente en mi entorno familiar, sino que habia un... como un nivel de inconformidad. Este, yo llegué a pensar: 'erda pero porque soy así Negro. ¿Si me entiendes? Todas las cosas..."

We find stories in which the participants affirm that in their families, the members are recognized as victims and openly express that they will not have the same treatment in society; others try to teach their members to separate themselves from certain spaces, because experience has taught them that there are clear racial limits that it is better not to cross. In some family experiences, we observe people who alienate themselves to the level of feeling sorry for blacks and label them as defenseless or useless, while other families, resort to socioeconomic promotion as the appropriate way to be accepted within the dominant social group. 
(15) "She treated me better, to the two of us; she treated us better than the other [Marlin] ${ }^{9}$. She forced the other one, forced her to do many shores". (Helena, 2009)

A mí, a nosotros dos nos trataba mejor que a la otra [Marlin] A la otra la ponía, la ponía a hacer bastante oficio.

(16) “(...) what happens now is that ... already in this last years I..., is like I had been acquiring [consciousness], but first, I did not pay attention, it was like, as I am black and they do not want me there, they do not love me because I am humble, because I am thick". (Andrea, 2009)

\section{(...) lo que pasa es que uno como que abora, ya en esto últimos años uno} como que va cogiendo [consciencia], pero antes uno como que no le le paraba bolas, uno estaba como, como yo soy negro y no me quieren abi, no me quieren porque soy humilde, porque soy bruto.

(17) I am beyond all that at this time; Sure! It took several years for me to understand that I'm a person who has the right to equality, but the thing is that you learn very young, at home, the inferiority thing, but now I am convinced that I am, like everybody else, the same than the others, so that's why I no longer feel, I do not feel like I'm inferior”. (Karina, 2009)

"Yo hoy en día estoy por encima de todo eso en estos momentos; iclaro! tuvieron que pasar varios años para que yo pudiera comprender eso, que soy una persona que tengo derecho a la igualdad, pero es que uno aprende desde muy pequeño, en la casa, eso la inferioridad, pero abora estoy convencida de que yo, como todas las personas, soy igual a la las demás, entonces por eso ya no siento, no me siento como como inferior".

The answers given by the agents of socialization carry the socio-racial hierarchization handled within the dynamics in Cartagena; they recognize the behavioral axes that make room for social relationships, but they also know this interaction demands knowledge about the behavior that subjects must have in order to avoid infringement to the established norms linked to the social role they play.

9 Marlin is the sister of Helena, our participant. Helena told us that her mother discriminated against her sister Marlin because she was the one with the darkest skin among her children. Helena told us that her mother considered Marlin inferior, incapable, and constantly reminded her how much she disliked her presence. This was the only case in which one of the parents physically, verbally and psychologically assaults a child because she perceives her as black. 


\section{Verbal}

The information that was included in this dimension was cataloged as responses to racism through discursive forms. Although we know that propagation of ideologies, knowledge, beliefs, and values is carried out by means of language (Zaidi, 2012; Van Dijk, 2016; Van Dijk, 2009; Woolard, 1992), there are parts that must be distinguished, since they enclose what concerns to the message as a socializing element. Within families, according to the participants, racist speech is given, that is, negative comments about the "other" blacks are often made; a discourse of otherness and a distance between the "blacks at home" and the rest:

(18) Then and she always said "oh! Look at that ugly Black", "Look what you went to look for". (Miladys, 2009)

"Entonces y ella siempre decía "iay! que mire ese Negro maluco", "mira que fue lo que fuiste a buscar"

(19) There those Blacks! (...) For example, the people of the village up there, they say these people, those Black people, and what are we!? (LAUGH) That is, they talk about Black people but not including themselves, that's why I say it". (Karina, 2009) "iAbi esos Negros! (...) por ejemplo, la gente del pueblo de allá arriba, que esa gente esa gente Negra que no sé qué, ajá ey nosotros qué somos? (RISAS) o sea hablan de la gente Negra pero no incluyéndose ellos, por eso es que lo digo".

We see that the agents of socialization use the demonstrative pronoun "those" to mark distances and discursively recognize the rest of black people as the Others. As stated, nicknames also play a role within the family, the member whose skin is darker, their nose broader or their hair curlier, will be labeled with a nickname that hyperbolizes their characteristics or that simply refers to these in a "humorous" way.

(20) "My mom said: “iRotten coconut smelling Black!” (Helena, 2009).

"Mi mamá decía "iNegro hediondo a copra!"

(21) "In the family they always called us "hey the flat-nosed!" (Ana, 2006).

"En la familia siempre nos decían, iEh tú, la ñata!"

(22) "When I was little, in my auntie's house they called my brother little black boy with burned feet because the little black boy with burned is the one who stirred the water, but all the time, little black boy who stirred the water. As it is supposes that water is crystalline and then if a Black person gets into she/he will stir it, he will darken it then (LAUGH)." (Martha, 2009). 
"Cuando pequeña, en la casa de la tía a mi hermano le decían negrito de pies quemaos porque el negrito de los pies quemaos es el que revuelve el agua, pero a cada rato, negrito revuelve el agua, AJÁ como el agua se supone que es cristalina y luego si se mete una persona Negra va a revolverla, la va a oscurecer entonces (RISAS)."

We distinguish two types of messages: protective and proactive (Barr \& Neville, 2008). The protective messages will be understood as those that are pronounced with the unique purpose of preventing socialized agents from living racist experiences in society. These messages are characterized because they seek individuals who leave home to accept the racism that exists in the city without opposition, and for that, the socialized agents deconstruct their racial identity and shape it; parents project their experiences in their socializing discourse.

The messages they transmit generate knowledge and reproduce the forms of discrimination that are practiced in Cartagena every day. We speak then of parents teaching their children to "deny their racial identity", not because of prejudicial reasons per se, but because the experience itself has taught them that recognition, acknowledging themselves as black, exposes them to be the object of racial discrimination.

(23) My grandmother used to say "that's why I told my daughters do not to lookthen, there was contradiction- do not look for color, look for hair, so that the children come out better. (Merly, 2006)

"Mi abuela decía "por eso yo a mis hijas les decía no busquen-entonces, abi se contradecía- no busquen color, busquen pelo, para que salgan los hijos mejor" (risas)."

(24) I heard from my grandmother (...) that the Blacks in this family were already numbered. " (Carlos, 2006)

"Yo llegué a escuchar de parte de mi abuela (...) que los Negros en esta familia ya estaban contados."

The fact that the grandmother expressed that "the blacks in that house were numbered" implies that actions are being taken, that they are teaching their members that building a family with black people is an action that will not be permitted. We also noted that protective messages were often linked with actions, since they are established as a way to authorize how they have decided to face racism in the city:

(25) (...) they straightened my hair since I was a child so that they did not give me any trouble [the school]". (Martha, 2009) 
"(...) a mi me alisaban el cabello desde pequeña para que no me pusieran pereque [En el colegio]"

(26) Since you are a little girl, they are putting those stereotypes right and way, and that does not allow you to value that identity, so I felt like ashamed for that, the hair." (Martha, 2009)

"Ya desde pequeña enseguida le van colocando a uno estereotipos y que no le permiten como valorar esa identidad, entonces yo me sentía como avergonzada por eso, el pelo”.

Regarding the proactive messages, only a few of the participants decided to transmit to their children racial pride, beliefs, and values associated with the Négritude. Many of the participants expressed their critical attitude towards messages reproduced inside their own homes:

(27) My wife told me that a little boy was treating a son of mine as a Nigro, then my wife ... [I asked her] so, what did you say? [She answered] So, I told him that when he called you black again tell him "I'm black but intelligent". Then I told her not to say that, I told her not to teach him that because those ideas will remain in his subconscious that being black is a bad thing and that he has to be using always "but" to excuse himself for being black; like saying "Ok, I'm fucked for being black, but at least I must be intelligent"... [wife answered] "no, no, is not for him to defend himself" [our participant respond] No! tell him something else, tell him not to pay attention, to call him black, to call him white, yellow, call him blue, but does not use that "but", we are since now, since his childhood creating a complex giving him to understand that it is bad to be Black. (Pedro, 2006)

"Mi esposa me dijo que un niñito trataba de Negro al hijo mío, entonces mi esposa... [yo le pregunté] ajá ¿tú que le dijiste? [Ella respondió] yo le dije que cuando le diga Negro le responda "yo soy Negro pero inteligente". Entonces yo le dije que no dijera eso, no le enseñara eso porque se le va quedando en el subconsciente de que es malo ser Negro y que tiene que estar usando siempre "pero" pa' excusarse que es Negro; como diciendo, "bueno ya, me jodí por ser Negro, pero tengo que ser inteligente".. [la esposa responde] "no, no, es pa' que se defienda" [nuestro participante responde] ino, dile otra cosa! que no preste atención o él que le diga Negro, que le diga blanco, amarillo, que le diga azul, pero no use el "pero" ese, ya lo estamos abora de chiquito acomplejando dándole a entender que es malo ser Negro".

(28) Now I've been working, "look girl we are different, everyone is different, you cannot be identical to me, you are like that and there is no one like you" (...) and when someone appears [little girl] "look mom! Blacks like us on television. She tells me "mommy, they are Black, all my family is Black". I say yes, your whole 
family is Black. Then she has been learning ... and they have given her many books where black girls appear, songs about...

E: that is, are you trying to make an effort so that she has readings where there are Black people in it and all that?

C: Exact. Yes, yes. And to reinforce tell her that she must love herself. (Carmen, 2006)

"Ya abora la be ido trabajando, mira niña nosotros somos diferentes, todo el mundo es diferente, tú no puedes ser igual a mí, tú eres así y no bay nadie (...) y cuando sale imira mami! Ve Negros como nosotras en la televisión. Me dice "ve mami, ellos son Negros, toda mi familia es Negra". Digo sí, toda tu familia es Negra. Entonces ya ella lo ba ido... y le han regalado muchos cuentos donde aparecen niñas Negras, canciones de...

E: o sea itú tratas de hacer como un esfuerzo para que ella tenga pues sí lecturas donde haya gente Negra y todo eso?

C: exacto. Sí, sí. Y a reforzarle, decirle que se tiene que querer".

Societies have always been an interconnection of relationships that exert an avid influence on subjects. Roles and affiliation to specific socio-racial groups determine the interactional relationships that arise in spaces where individuals with divergent social backgrounds come together. When this happens, the systems of values that govern and that are accepted in the community are made explicit. The outcome we want to reach is that identity is an extremely complex and difficult element to define, which is summarized as "what I believe I am" as opposed to "what I believe the other is" (Hall, 1992). It is from the idea of identity as a relational process (Restrepo, 2007; Hall \& Du Gay, 1996) that differences are built. In this research, we worked from the perspective of the victims of racism; the interviews orbited around the way they believed that perpetrators perceived them, something that David Mellor (2003) calls perceived racism. When subjects are constructing themselves, they resort to the elements that differentiate them from Others. For that reason, the conceptualizations that are made about the racial and ethnic values are characterized by being located in the social identities of the individual, since being black has social specific implications, and comes hand in hand with a whole series of stereotypes and meanings.

\section{Conclusion}

Having gone deeper into the content of the racial socialization messages, we approach all the possible responses to racism adopted by the agents of the socialization process. The study of this topic was laborious and interesting insofar as we are seeing socialization from the perspective of the socialized subjects, who later narrate their family histories and tell which are their parenting strategies regarding race-related issues. 
The critical discourse analysis of the experiences narrated by the participants offered perspectives on the types of racialized messages that are issued within families. In the same way, it allowed us to recognize the structure that the participants use to relate those events they experienced; the structure of the narratives was especially simple, they contained a summary, an orientation, and a description. Parallel to that, in these narrations, numerous attribute constructions directly related to the adjectives appear. Throughout the interviews, it was possible to notice how macro propositions such as "you have to improve the race" or "look for a white person" are repeated, clearly, these macro propositions are the central theme of the stories indicating that they are carriers of representations about the racial issue within the family of the participants.

Our interviewees are people who, despite recognizing themselves as Afro-descendants, continue having problems regarding the identification and approach of racist events, that is, despite the recognition, there are attitudes and actions so naturalized that the racist "hue" is not dimensioned in them. The interviewees who did not find the messages with a eugenic dimension problematic such as "washing the race" or "improving the race" did not carry out evaluations regarding the events they experienced, notwithstanding they know how the situation occurred and that there are questionable edges in them. Still, there were others who went beyond and during the evaluation process answered the question about why socializing agents responded to certain situations in a certain way.

The messages that take place within the black families in Cartagena have high contents considered discriminatory. The central axis is the racial improvement and the establishment of marital relationships with people perceived as white. This work reveals how racism survives and mutates on a daily basis. The messages of socialization that are issued within the black families in Cartagena, act as a discursive response associated with actions that competently help the preparation of children for their social life.

Racism remains and is reaffirmed in the daily life of families through the forms they have assumed as responses to this phenomenon. We found that the responses to the problem are understood in terms of four types: biological, cultural, behavioral and verbal; and although this characterization only offers a global view of the answers assumed by the families so that the children are able to adapt to the social environment, we believe that it opens the possibility of continuing to deepen into a topic that has not been addressed. It is clear that these responses in pursuit of the adjustment to the racist dynamics of the city can be read as a kind of complicity with those who exert social control through Problematization, Marginalization, and Containment (Essed, 1991) derived from racial factors. However, these protective messages have the sole intention of protecting the members of the family nucleus, even though in the process, they reinforce racist practices and ideologies. 


\section{References}

Bankhead, T. \& Tabora, J. (2014). Hair It Is: Examining the Experiences of Black Women with Natural Hair. Open Journal of Social Sciences, 2(1), 86-100. Retrieved from https://www. scirp.org/journal/PaperInformation.aspx?paperID $=41744$

Barr, S. \& Neville, H. (2008). Examination of the Linkbetween Parental Racial Socialization Messages and Racial Ideology among Black College Students. Journal of Black Psychology, 34, 131155. Retrieved from https://journals.sagepub.com/doi/10.1177/0095798408314138

Beharry, P. \& Crozier, Sh. (2008). Using Phenomenology to Understand Experiences of Racism for Second-Generation South Asian Women. Canadian Journal of Counselling, 42, 262-277. Retrieved from https://pdfs.semanticscholar.org/1895/ eab3691177cc6ca9baf014282a983567d419.pdf

Bellinger, W. (2007). Why African American Women Try to Obtain 'Good Hair'. Sociological Viewpoints, 23, 63-71. Retrieved from http://citeseerx.ist.psu.edu/viewdoc/ download?doi=10.1.1.473.1938\&rep= rep1\&type $=$ pdf

Bonilla, E. (1997). Rethinking Racism: Towards a Structural Interpretation. American Sociological Review, 3(62), 465-480. Retrieved from https://www.jstor.org/ stable/2657316?seq=1\#metadata_info_tab_contents

Cunin, E. (2003). Identidades a flor de piel. Bogotá: ICANH, Uniandes, IFEA, Observatorio del Caribe Colombiano.

Davis, B., Smith-Bynum, M., Salem, F., Francois, T. \& Lambert, Sh. (2017). Racial Socialization, Private Regard, and Behavior Problems in African American Youth: Global Self-Esteem as a Mediator. Journal of Child and Family Studies, 3(27), 709-720. Retrieved from https:// link.springer.com/article/10.1007/s10826-016-0601-8

Ellis-Hervey,N.,Doss,A.,Davis,D.,Nicks,R.\&Araiza,P.(2016).AfricanAmericanPersonalPresentation: Psychology of Hair and Self-Perception.Journal of Black Studies, 19, 1-14. Retrieved from https://journals.sagepub.com/doi/abs/10.1177/0021934716653350?journalCode =jbsa

Essed, P. (1991). Understanding Everyday Racism. An Interdisciplinary Theory. Newbury Park: SAGE publications.

Fairclough, N \& Wodak, R. (2000). Análisis crítico del discurso. In T.A. Van Dijk (ed). Estudios sobre el discurso. Una introducción multidisciplinaria. Vol II (pp. 367-404). Barcelona: Gedisa.

Fonseca, C. (2014). Racismo en la escuela cartagenera. Palobra, 14(14), 28-45. Retrieved from https://revistas.unicartagena.edu.co/index.php/palobra/article/view/47

Gil, F. (2010). Vivir en un mundo de 'blancos'. experiencias, reflexiones y representaciones de 'raza' y clase de personas negras de sectores medios en Bogotá D.C. (Tesis de 
maestría). Universidad Nacional de Colombia. Retrieved from http://www.bdigital.unal. edu.co/3135/1/478264.2010.pdf

Hall, S. (1992). The Question of Cultural Identity. In D. Held, S. Hall \& T. McGrew (eds.) Modernity and Its Futures. Cambridge: Polity Press.

Hall, S. \& Du Gay, P. (1996). Questions of Cultural Identity. London: SAGE Publications.

Hargro, B. (2011). Hair Matters: African American Women and the Natural Hair Aesthetic. (Master Thesis). Georgia: Universidad de Georgia. Retrieved from https://scholarworks. gsu.edu/cgi/viewcontent.cgi?article $=1095 \&$ context $=$ art_design_theses

Hughes, D. \& Chen, L. (1999). The Nature of Parents' Race-Related Communications to Children: A Developmental Perspective. In L. Balter \& C. Tamis-LeMonda (eds.) Child Psychology: A Handbook of Contemporary issues. New York: Psychology Press.

Hughes, D., Rodríguez, J., Smith, E., Johnson, D., Stevenson, H. \& Spicer, P. (2006). Parents' Ethnic-Racial Socialization Practices: A Review of Research and Directions for Future Study. Developmental Psychology, 5(42), 747-770. Retrieved from https:/www.ncbi. nlm.nih.gov/pubmed/16953684

McRoy, R. (1996). Racial Identity Issues for Black Children in Foster Care. In S. Logan (ed.), The Black Family. Strengths, Self-Help, and Positive Change. Boulder: Westview Press.

Mellor, D. (2003). Contemporary Racism in Australia: The Experiences of Aborigenes. Personality and Social Psychology Bulletin, 4(29), 474-486. Retrieved from https://journals.sagepub. com/doi/abs/10.1177/0146167202250914?journalCode $=$ pspc

Nelson, J. \& Dunn, K. (2017). Neoliberal Anti-Racism: Responding to 'Everywhere but Different' Racism. Progress in Human Geography, 1(41), 26-43. Retrieved from https://journals. sagepub.com/doi/abs/10.1177/0309132515627019

Posada, C. (2003). La raza negra en Colombia: antioqueños y chocoanos. Estudios de Literatura Colombiana, 12, 105-109. Retrieved from https://aprendeenlinea.udea.edu.co/revistas/ index.php/elc/article/view/10539/9697

Quijano, A. (1999). iQué tal raza! Debate, 48, 141-151. Retrieved from http://repositorio. flacsoandes.edu.ec:8080/handle/10469/5724

Quijano, A. (2000). Colonialidad del poder, eurocentrismo y América Latina. En E. Lander (ed.) La colonialidad del saber, eurocentrismo y ciencias sociales. Buenos Aires: CLACSO.

Quintero, 0. (2010). Racismo, algunas definiciones y aproximaciones desde las ciencias sociales. In 0. Hoffman \& 0. Quintero (eds.), Estudiar el racismo, textos y herramientas. Antología de textos teóricos traducidos al español referidos al estudio del racismo. México: AFRODESC/EURESCL. 
Restrepo, E. (2007). Identidades: planteamientos teóricos y sugerencias metodológicas para su estudio. Jangwa Pana, 5, 24-35. Retrieved from http:/www.ram-wan.net/restrepo/ documentos/identidades-jangwa\%20pana.pdf

Staudigl, M. (2012). Racism: On the Phenomenology of Embodied Desocialization. Continental Philosophy Review, 1(45), 23-39. Retrieved from https://ink.springer.com/ article/10.1007/s11007-011-9206-5

Van Dijk, T. (2009). Discourse, Ideology and Context. Folia Lingüística, 1-2(35), 11-22. Retrieved from

https://pdfs.semanticscholar.org/17c8/4082f6f6e0b7e03f1e89bbddd54c3b36047c.pdf

VanDijk,T.(2016).IdeologyandDiscourseAnalysis.JournalofPoliticalIdeologies2(11),115-140.Retrieved from https://pdfs.semanticscholar.org/1fea/65781d4e83e29d10ce4475822d08d686f3bb.pdf

Villarreal, K. (2018). Gestionando la identidad: el cabello como capital. Revista Brasileira do Caribe, 36(18), 73-84. Retrieved from http://www.periodicoseletronicos.ufma.br/index. php/rbrascaribe/article/view/10049

Viveros, M. (2009). La sexualización de la raza y la racialización de la sexualidad en el contexto latinoamericano actual. Revista Latinoamericana Estudios de Familia, 1, 63-81. Retrieved from http://www.bivipas.unal.edu.co/handle/10720/663

Wade, P. (1997). Gente negra, nación mestiza: las dinámicas de las identidades raciales en Colombia. Bogotá: Ediciones UNIANDES.

Wade, P. (2003). Repensando el mestizaje. Revista Colombiana de Antropología, 1(39), 273296. Retrieved from http://www.redalyc.org/pdf/1050/105018181009.pdf

White-Johnson, R., Ford, K. \& Sellers, R. (2010). Parental Racial Socialization Profiles: Association with Demographic Factors, Racial Discrimination, Childhood Socialization, and Racial Identity. Cultural Diversity and Ethnic Minority Psychology, 2(16), 237-247. Retrieved from https://www.ncbi.nlm.nih.gov/pmc/articles/PMC2864943/

William, D. \& Collins, Ch. (2001). Racial Residential Segregation: A Fundamental Cause of Racial Disparities in Health. Public Health Reports, 116(5), 404-417. Retrieved from https:// www.ncbi.nlm.nih.gov/pubmed/12042604

Woolard, K. (1992). Language Ideology: Issues and Approaches. Pragmatics, 3(2), 235-249. Retrieved from https://journals.linguisticsociety.org/elanguage/pragmatics/article/view/225.html

Zaidi, A. (2012). Language of Ideology/Ideology of Language: Notes on Theory and Practice. Journal of Postcolonial Cultures and Societies, 1(3), 71-88.

Zebrowitz, L. (1996). Physical Appearance as a Basis for Stereotyping. In N. MacRae, M. Hewstone \& C. Stangor (eds.) Foundation of Stereotypes and Stereotyping (pp. 79-120). New York: Guilford Press. 